\title{
Estimation of Yield Losses of Three Corn Varieties Due to Stem Borers Sesamia cretica Led. and Ostrinia nubilalis(Hb.) in El- Bostan Region, El-Behiera Governorate
}

\author{
Al-Eryan M. A. S., Abu- Shall Amany M. H., Huesien Hanaa S. and Ibrahiem H. K. \\ Dept. Applied Entomology and Zoology, Faculty of Agriculture, Alexandria University
}

\begin{abstract}
This study aimed to assess the yield losses in three varieties of maize (white, yellow and sugary corn) due to stem borers; Sesamia critica and Ostrinia nubilalis under field conditions and insecticide treatment. The yield losses was conducted using the conventional and analytical methods to compare whichever more accurate.

The analyzed results of the present study shows that the grain weight/ear of intact maize were significantly influenced by the corn variety, while, it wasn't affected by insecticide treatment. The highest grain weight was obtained in white corn $154.33 \mathrm{gm} / \mathrm{ear}$, on the contrary, the sugary corn recorded the lowest grain weight ( $36 \mathrm{gm} / \mathrm{ear})$. The means of grain weight / ear were clearly decreased under stem borers, S. creticae and $O$. nubilalis infestation, with a higher susceptibility for the white corn.

Under insecticidal treatment, the yield losses due to S. cretica, and O. nubilalis were reduced by $44.26 \%$ and $60.87 \%$ in white corn, and by $8 \%$ and $41.27 \%$ in yellow corn, respectively. The yield losses due to plant absence were, $3.75,4.8$ and $10.53 \%$ for white, yellow and sugary corn, respectively.

The present results indicate that the analytical method was more accurate than the conventional method, whereas, analytical method put in consideration yield loss from absent plants during assessment of yield losses.
\end{abstract}

\section{Keywords: Yield losses- Stem borers - Corn - Ostrinia nubilalis- Sesamia cretica.}

\section{INTRODUCTION}

Maize (Zea mays L.) (Family: Graminae)is an important crop in many developing countries for food and industrial cereal (FAO, 1998 and Ande et al., 2008). It belongs to class of cereals that cultivated under a wide range of environmental conditions (Mbahet al., 2009); although, grain yields are affected by nature and physical conditions as well as nutrients storage of the soil.The economic importance of maize has been greatly increased since it is used for consumption of human and livestock's; and as a source of industrial raw material for the production of bio products such as oil, alcohol and starch.

In Egypt, maize is a major cereal crop; in 2013 about 2 million Feddans were cultivated with maize, which produced about 7 million tons of grain yield (Metwally, 2015). In 2015, the mean weight of grains yield / Feddan was 10.88 Ardabs/Feddan $\left(\right.$ Ardab $=140 \mathrm{Kg}$, Feddan $\left.=4200 \mathrm{~m}^{2}\right)$. Percentage of grain yield loss was $53.62 \%$ due to lepidopteran stem borers' infestation (Massoud et al., 2016).

In Egypt, population increase rate of insect pests is high $(2.55 \%$ annually), resulting in increased pressure on arable land. Consequently, pest pressure was increased on maize plants, which are subject to infestation with a variety of insect pests. Most important of which is the lepidopteran of stem borers, Sesamia cretica Led. (Noctuidae), Ostrinia nubilalis (Hb.) (Pyraustidae) and Chilo Agamemnon (Bles.) (Crambidae). They attack the maize plants throughout the different stages of their growth causing the characteristic symptoms of dead hearts, elongate tunnels and circular holes, respectively, Due to these infestations the grain yield subsequently affected (Mesbah et al., 2002a; Sabbour, 2002 andIdraw\& Al-Jouri, 2007).The stem borers, $S$. creticaand $O$. nubilalisare regarded among the major factors affecting the productivity of growing maize plants and causing great damage and yield loss (Abd El-Gawad et al., 2002).The Pink Stem Borer, S. Creticais isaserious pest threatening maize plants in Egypt (Metwally, 2015).

Injury due to feeding by European corn borer, $O$. nubilalis is one stress that can promote the progression of stalk rot, contributing to the development of stalk rot when larvae tunnel into stalks and create points for fungal invasion. European corn borer can also serve as a vector of fungal pathogens. Borer feeding also causes physiological stress that predisposes the maize to stalk rot development (Bergstrom \& Nicholson, 1999 and White, 1999).

The importance of making quantitative assessments of yield losses caused by pest attack on crops has long been recognized. Some reasons for making such assessments are the establishment of the economic status of specific pests (Golebiowska and Romankov, 1968); to find the infestation that justifies control (Chiarappa et al., 1970) and to give a basis for directing future research and agriculture planning (Walker, 1967). Yield losses caused by corn insect pests were investigated and estimated by several authors such as Abdel Rahim et al., (1992); Ismail et al., (1993); Mansour et al., (1994) and AlEryan\& El-Tabbakh, (2004). 
Loss assessments are performed under natural field conditions either by regression analysis (Gage \&Mukerji, 1978)or by the analytical method (Lubischev, 1932 and Judenko, 1973). The analytical method is based on the comparison of yields of two sets of plants as far as known growing under identical conditions, except that one set is unattacked by a specific pest and the other attacked. The investigator thus avoids the false assessment of damage obtained by comparison yields from plots treated with a pesticide with yields from those untreated. Such a comparison does not take into account the fact that pest control might be incomplete. There is also the possibility that the treatment may have a direct effect on the crop (Judenko, 1973). Some authors have used replicated field trails to assess crop losses as a result of pest infestations, using randomized blocks or on randomly selected plots in fields. In their experiments, they have kept some plots free from pests by blanket insecticide treatments or other control measures whereas the plants of the other plots are allowed to be damaged by naturally occurring populations of the same pests. Several authors have stated that it is dangerous to use an insecticide to assess the increase in crop production that resulted from the control of any given pest, unless the cumulative effect of the insecticide was ascertained, as it might directly or indirectly influence the status of many other insect species (Pickett, 1954 and Kumar, 1984).

Attention should be paid for assessing yield loss due to these stem borers, yield loss is a prerequisite step for the determination of economic injury levels (EILs) that represent a salient tool for a decision making program and /or for initiating integrated pest management (IPM) programs in maize field. It is worth mentioning that EIL is an important and salient factor in initiating a proper and intact integrated pest management program (IPM) for the studied pests. The economic injury level is not representing a permanent constant value, but it differs according locality, product price and insecticide cost. In other words it is a dynamic value (Massoud et al., 2016).

The present study aimsto estimate the yield losses of three corn varieties due to infestation with stem borers; Sesamia critica, and Ostrinia nubilalis under field conditions.

\section{MATERIALS AND METHODS}

1: Estimation of grain yield losses of three corn varieties affected by infestation with two stem borers under treatment with insecticide:

The experiment was carried out in El-Bostan region $\left(30^{\circ} 49\left[41.52 \square \mathrm{N}, 30^{\circ} 31\right] 58.44 \square\right.$ E), ElBehiera governorate. It was a randomized complete blocks design in a split-plot system with three replicates. Applications of insecticide (treated and untreated) were assigned to main plots and corn varieties were assigned to sub-plot. Each sub-plot measured 3 meters long and 90 centimeter wide, and the total experimental area was $9 \mathrm{~m} . \times 1.8 \mathrm{~m}$.

The tested insecticide:-

Common name:-Emamectin

Trade name:-Emamectin Benzoate or Jasper 3.4 $\% \mathrm{ME}$

Chemical name:- $\quad(4 " \mathrm{R})-4$ "-deoxy-4"(methylamino) avermectin B1 benzoate Shandong united pesticide industry Co., LTDChin

Three corn varieties (white, yellow and sugary) were sowed in July, 2015. The corn varieties that used in the experimental area were white corn ("SC10" =single crosses), yellow corn ("Pioneer 3062 " =yellow two single crosses) and sugary corn ("Cv.NS30"=non-caloric sweetened). After 15 days from sowing, number of naturally absent plants was recorded. At 30 days, the plants infested with Sesamia cretica were labeled by rings of yellow ribbons to be under observation till yield estimation. This procedure was applied every two weeks until 45 days from sowing date. In addition, at 45 days age, infested plants with Ostrinia nubilalis, were recorded and labeled by rings of red ribbons. Half of main plots were sprayed with the insecticide (Emamectin). The field recommended concentration of insecticide (120 ml/feddan) was used for application three times at 15, 45 and 70 days from sowing date.

At harvesting time, the next yield parameters were estimated:-

$\mathrm{N}=$ total number of plants per plot

$\mathrm{Y}^{*}=$ mean grain yield per intact plant

$\mathrm{Y}=$ mean grain yield per infested plant

ACT = Actual grain yield of stand plants per plot

At harvesting time, the yield loss (LOSS) and percentage of economic loss (\% LOSS) were calculated according to Judenko (1973) as follows:-

EXP $($ Expected yield $)=$ No. of plants $(\mathrm{N})$ per plot $\mathrm{X}$ Intact plant yield $\left(\mathrm{Y}^{*}\right)$

ACT $($ Actual yield $)=$ No. of plants $(\mathrm{N}) \times$ absent or infested plant yield $(\mathrm{Y})$

LOSS $=$ EXP - ACT

$\%$ LOSS $=$ LOSS $/$ EXP $\times 100$

3.2. Determination of grain yield losses (kg/plot) of three corn varieties due to stem borers by conventional and analytical methods:

The grain yield loss ( $\mathrm{kg} / \mathrm{plot})$ of three corn varieties due to stem borers was calculated by using conventional (insecticide treatment) and analytical methods (Judenko (1973). Analytical method put in consideration yield loss from absent plants during assessment of yield losses but conventional method estimate yield losses of only plant stands. 


\section{RESULTS AND DISCUSSION}

1. Estimation of grain yield losses of three corn varieties due to infestation with two stem borers under treatment with insecticide:

The yield of corn varieties under pest infestation in treated and untreated plots, were clarified in Tables (1, 2 and 3) and Figure (1). Analysis of variance showed that grain weight/ear of intact maize were significantly influenced by the corn variety, while, it wasn't affected by insecticide treatment. The highest grain weight was obtained in white corn $154.33 \mathrm{gm} /$ ear, while the sugary corn recorded the lowest grain weight 36 gm/ear (Table 1). It was clear that the insecticide treatment caused an increase of grain weight by $3.44 \mathrm{gm} /$ ear. Massoudet al. (2016) resulted that insecticidal treatments led to subsequent increases in the mean yield of maize grains which have no significant difference between them or the control.

Regardless the insecticide treatment, the means of grain weight/ ear for three corn varieties were significantly different, where, the means of grain weight for white, yellow and sugary corn were 145 , 108.17 and $37 \mathrm{gm} /$ ear, respectively.

Data in Table (2) shows the means of grain weight / ear of infested maize varieties with the sugar-cane borer, $S$. cretica under treatment of insecticide. Regardless the corn varieties, the difference between grain weight of treated and untreated plants reached 9.34 gm/ear. The grain weight /ear of corn varieties were descending from white grain maize (66.5 gm/ear). to sugary maize (19 gm/ear).

It was found that the highest grain weight /ear were recorded by white grain maize under insecticide treatment $(50 \mathrm{gm} / \mathrm{ear})$, while, the lowest grain weight (18 gm/ear) was recorded by untreated sugary maize. Generally, the grains weight was clearly decreased under $S$. creticae infestation, when compared with the grains weight in intact plants (Table1).

Means of grain weight / ear of infested maize varieties with the European corn borer, O. nubilalis under treatment of insecticide were presented in a Table(3). Over all the studied varieties, the difference between treated and untreated plants reached $21.0 \mathrm{gm} / \mathrm{ear}$. Also, grains weight /ear over insecticide treatments were descending from white maize (85.50 gm/ear) to sugary maize (35.17 gm/ear). In the meantime, the highest weight of grains/ear were recorded in white grain maize under insecticide treatment $(105.33 \mathrm{gm} / \mathrm{ear})$, while, the lowest grain weight/ear were recorded in the untreated sugary maize plants (34 gm/ear).

Estimation of grain yield losses $(\mathrm{kg} / \mathrm{plot})$ due to stem borers in untreated and treated white corn are illustrated in Table(4). Percentages of yield losses due to infestation with $S$. cretica, and $O$. nubilalis were 1.83 and $1.38 \%$ for untreated plots, respectively. These percentages of yield losses were reduced to 1.02 and $0.54 \%$ in case of treated plots. While, yield losses due to absent plants was $3.75 \%$ and $4.78 \%$ for untreated and treated plots, respectively. It was clear that the insecticide treatments decrease the white corn yield losses that caused by pests infestations as showed in Table (5). The reduction percentages of yield losses in white corn variety due to $S$. cretica, and $O$. nubilalis were 44.26and 60.87, respectively, under treatment with insecticide.

Table 1: Mean of grain weight/ear of intact maize varieties under insecticide treatment.

\begin{tabular}{|c|c|c|c|c|c|c|}
\hline \multirow{3}{*}{$\begin{array}{l}\text { Corn varieties } \\
\text { Insecticide treatments } \\
\text { Treated } \\
\end{array}$} & \multicolumn{5}{|c|}{ Grain weight/ear (gm) } & \multirow[b]{2}{*}{$\begin{array}{c}\text { Insecticide } \\
\text { treatments` means }\end{array}$} \\
\hline & Yellow corn & \multicolumn{2}{|c|}{ White corn } & \multicolumn{2}{|c|}{ Sugary corn } & \\
\hline & 103.00 & 154.33 & $\mathrm{a}$ & 38.00 & $\mathrm{ac}$ & $98.44 \quad \mathrm{~A}$ \\
\hline Un-treated & 113.33 & 135.67 & $\mathrm{ab}$ & 36.00 & $\mathrm{ac}$ & 95.00 \\
\hline Varieties`means & 108.17 & 145.00 & $\mathrm{~A}$ & 37.00 & $\mathrm{C}$ & 96.72 \\
\hline
\end{tabular}

Means with the same letter (s) are not significantly different.

Capital letters $=$ Significance between varieties and insecticide treatments. Small letters $=$ Significance between treatments.

Table 2: Mean grain weight/ear of infested maize varieties with the sugar-cane borer, $S$. cretica under treatment of insecticide.

\begin{tabular}{|c|c|c|c|c|}
\hline & \multicolumn{3}{|c|}{ Grain weight/ear (gm) } & Insecticide \\
\hline $\begin{array}{l}\text { Corn varieties } \\
\text { Insecticide treatments }\end{array}$ & Yellow corn & White corn & Sugary corn & treatments' means \\
\hline Treated & 43.0 & 50.00 & 20.00 & 37.67 \\
\hline Untreated & 34.0 & 33.0 & 18.00 & 28.33 \\
\hline Varieties`means & 38.5 & 66.5 & 19 & \\
\hline
\end{tabular}

* Means are insignificant at 0.05 and 0.01 
Table 3: Mean grain weight/ear of infested maize varieties with the European corn borer, Ostrinia nubilalis under treatment of insecticide.

\begin{tabular}{|c|c|c|c|c|}
\hline \multirow[b]{2}{*}{$\begin{array}{l}\text { Corn varieties } \\
\text { Insecticide treatments }\end{array}$} & \multicolumn{3}{|c|}{ Grain weight/ear (gm) } & \multirow{2}{*}{$\begin{array}{c}\text { Insecticide } \\
\text { treatments` means }\end{array}$} \\
\hline & Yellow corn & White corn & Sugary corn & \\
\hline Treated & $85.67 \mathrm{a}$ & $105.33 \mathrm{a}$ & $36.33 \mathrm{a}$ & $75.78 \mathrm{~A}$ \\
\hline Un-treated & $64.67 \mathrm{a}$ & $65.67 \mathrm{a}$ & $34.00 \mathrm{a}$ & $54.78 \mathrm{~A}$ \\
\hline Varieties`means & $75.17 \mathrm{~A}$ & $85.50 \mathrm{~A}$ & $35.17 \mathrm{~A}$ & 65.28 \\
\hline
\end{tabular}

Means with the same letter (s) are not significantly different.

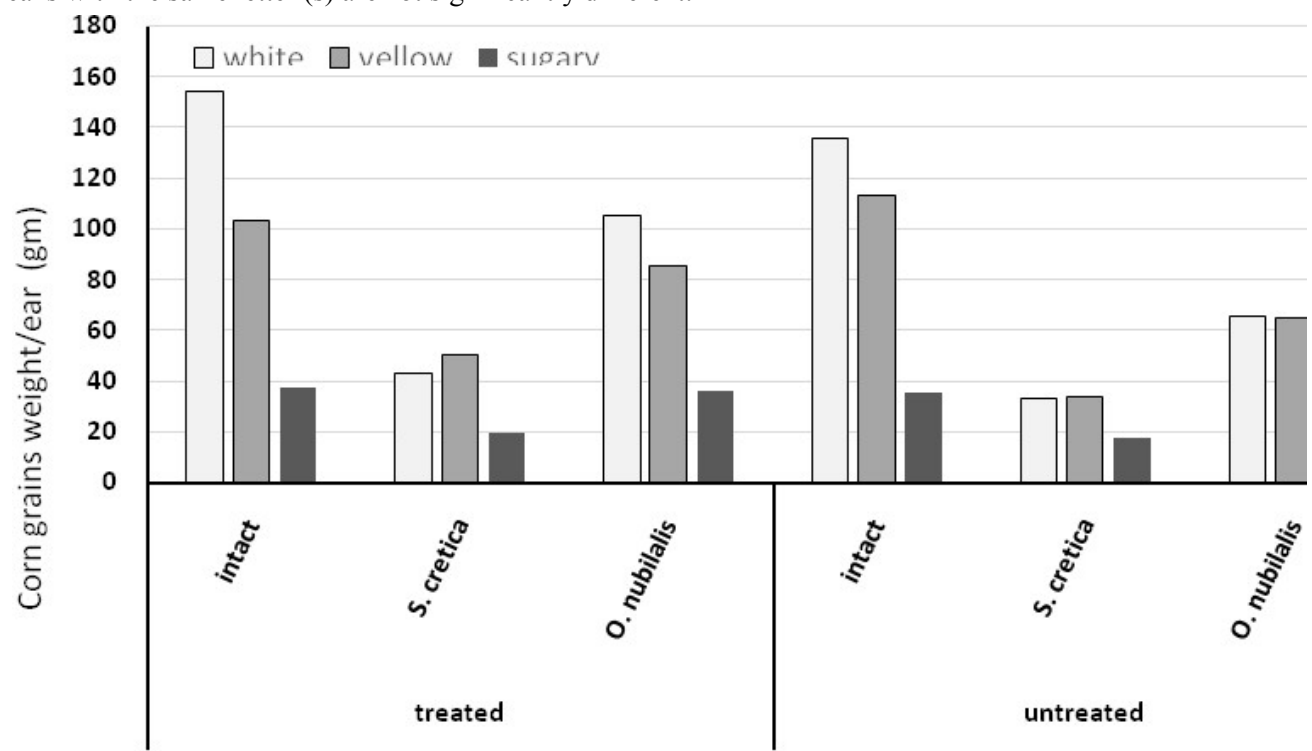

Insecticide treatment

Figure 1: Means of corn grain weight/ear as affected by maize varieties and insecticide treatment under stem borers infestation.

Table 4: Estimation of grain yield losses (kg/plot) due to stem borers in untreated and treated white corn.

\begin{tabular}{|c|c|c|c|c|c|c|c|c|c|c|c|c|}
\hline \multirow{3}{*}{ Plant status } & \multicolumn{6}{|c|}{ untreated } & \multicolumn{6}{|c|}{ treated } \\
\hline & \multirow{2}{*}{$\begin{array}{c}\text { No. of } \\
\text { plants } \\
(\mathrm{N}) \\
\end{array}$} & \multirow{2}{*}{$\begin{array}{c}\text { Plant } \\
\text { yield (kg) } \\
(\mathrm{Y})\end{array}$} & \multicolumn{4}{|c|}{ Grain yield (kg/plot) } & \multirow{2}{*}{$\begin{array}{c}\text { No. of } \\
\text { plants } \\
(\mathrm{N})\end{array}$} & \multirow{2}{*}{$\begin{array}{c}\text { Plant } \\
\text { yield } \\
(\mathrm{kg})(\mathrm{Y})\end{array}$} & \multicolumn{4}{|c|}{ Grain yield (kg/plot) } \\
\hline & & & EXP & ACT & $\begin{array}{l}\text { Loss } \\
(\mathrm{Kg})\end{array}$ & $\begin{array}{c}\% \\
\text { Loss }\end{array}$ & & & EXP & ACT & $\begin{array}{l}\text { Loss } \\
\text { (Kg) }\end{array}$ & $\begin{array}{c}\% \\
\text { Loss }\end{array}$ \\
\hline Intact & 1344 & $\begin{array}{c}0.136 \\
\left(Y^{*}\right)\end{array}$ & 182.78 & 182.78 & 0 & 0 & 1330 & $\begin{array}{c}0.154 \\
\left(Y^{*}\right)\end{array}$ & 204.82 & 204.82 & 0 & 0 \\
\hline Absent & 56 & 0 & 7.62 & 0 & 7.62 & 3.75 & 70 & 0 & 10.78 & 0 & 10.78 & 4.78 \\
\hline Infested with $S$. cretica & 36 & 0.033 & 4.90 & 1.19 & 3.71 & 1.83 & 22 & 0.05 & 3.39 & 1.1 & 2.29 & 1.02 \\
\hline Infested with $O$. nubilalis & 40 & 0.066 & 5.44 & 2.64 & 2.80 & 1.38 & 25 & 0.105 & 3.85 & 2.63 & 1.22 & 0.54 \\
\hline
\end{tabular}

EXP $($ Expected yield $)=$ No. of plants $(\mathrm{N}) \times$ Intact plant yield $\left(\mathrm{Y}^{*}\right)$

ACT $($ Actual plant yield $)=$ No. of plants $(\mathrm{N})$ xabsent or infested plant yield $(\mathrm{Y})$

LOSS $=$ EXP - ACT $\quad \%$ LOSS $=$ LOSS $/$ EXP $\times 100$

Table 5: The percentages of reduction in yield losses of white corn due to infestation by stem borers under treatment of insecticide.

\begin{tabular}{|c|c|c|c|c|}
\hline \multirow[t]{2}{*}{ stem borers } & \multicolumn{2}{|c|}{ \% Yield losses } & \multirow{2}{*}{ Decline in yield losses } & \multirow{2}{*}{$\begin{array}{c}\text { \% Reduction in yield } \\
\text { losses }\end{array}$} \\
\hline & untreated & treated & & \\
\hline S. cretica & 1.83 & 1.02 & 0.81 & $44.26 \%$ \\
\hline O. nubilalis & 1.38 & 0.54 & 0.84 & $60.87 \%$ \\
\hline
\end{tabular}


Table (6) illustrate the grain yield losses $(\mathrm{kg} / \mathrm{plot})$ due to two stem borers in untreated and treated yellow corn. Yield losses due to infestation with $S$. cretica, and $O$. nubilalis were 0.75 and $0.63 \%$ for untreated plots, respectively. They reduced to 0.69 and 0.37 for treated plots, respectively. While, yield losses due to absent plants was $4.8 \%$ and $3.89 \%$ for untreated and treated plots, respectively. The yield losses caused by $S$. cretica and $O$. nubilalis clearly reduced by using insecticide treatment (Table 7). The reduction percentages of yield losses in yellow corn variety were, 8 and $41.27 \%$ for $S$. cretica and $O$. nubilalis, respectively.

Percentages of grain yield losses (kg/plot) due to stem borers in untreated and treated sugary corn are illustrated in Table (8). Percentages of yield losses due to infestation with $S$. cretica and $O$. nubilalis were 0.09 and $0.04 \%$ for untreated plots, respectively. The percentages of losses were 0.40 and $0.04 \%$ for treated plots, respectively. While, yield losses due to absent plants were 10.53 and $8.58 \%$ for untreated and treated plots, respectively. It was clear that the insecticide treatments did not decrease the sugary corn yield losses that caused by pests infestations as showed in Table (9).

The two corn borers $S$. cretica and $O$. nubilalis which are regarded among the major factors affecting the productivity of growing maize plants and causing great damage and yield losses, (Abd ElMageed, and El-Gohary, 2007).The present results clearly demonstrated that the yield losses caused mainly by the infestation by stem borers. Early reports mentioned that maize yield losses due to pests in different countries are in agreement with the results of the present study. In Romania, yield losses can arrive to $60 \%$ as a result of $O$. nubilalis attack, (Paulian et al., 1976). Also, (Zeren et al., 1988) concluded that $S$. cretica infests maize throughout its development, from the seedling stage to maturity.

Table 6: Estimation of grain yield losses due to stem borers in untreated and treated yellow corn.

\begin{tabular}{|c|c|c|c|c|c|c|c|c|c|c|c|c|}
\hline \multirow{3}{*}{ Plant status } & \multicolumn{6}{|c|}{ untreated } & \multicolumn{6}{|c|}{ treated } \\
\hline & \multirow{2}{*}{$\begin{array}{l}\text { No. of } \\
\text { plants } \\
(\mathbf{N}) \\
\end{array}$} & \multirow{2}{*}{$\begin{array}{l}\text { Plant } \\
\text { yield } \\
(\mathbf{k g})(\mathbf{Y})\end{array}$} & \multicolumn{4}{|c|}{ Grain yield (kg/plot) } & \multirow{2}{*}{$\begin{array}{l}\text { No. of } \\
\text { plants } \\
(\mathbf{N})\end{array}$} & \multirow{2}{*}{$\begin{array}{c}\text { Plant } \\
\text { yield } \\
(\mathbf{k g})(\mathbf{Y})\end{array}$} & \multicolumn{4}{|c|}{ Grain yield (kg/plot) } \\
\hline & & & EXP & ACT & Loss & $\begin{array}{c}\% \\
\text { Loss }\end{array}$ & & & EXP & ACT & Loss & $\begin{array}{c}\% \\
\text { Loss }\end{array}$ \\
\hline Intact & 1323 & $\begin{array}{c}0.103 \\
\left(\mathrm{Y}^{*}\right)\end{array}$ & 136.27 & 136.27 & 0 & 0 & 1334 & $\begin{array}{c}0.113 \\
\left(Y^{*}\right)\end{array}$ & 150.74 & 150.74 & 0 & 0 \\
\hline Absent & 58 & 0 & 7.21 & 0 & 7.12 & 4.8 & 56 & 0 & 6.33 & 0 & 6.33 & 3.89 \\
\hline Infested with $S$. cretica & 16 & 0.034 & 1.65 & 0.54 & 1.11 & 0.75 & 16 & 0.043 & 1.81 & 0.688 & 1.12 & 0.69 \\
\hline Infested with O.nubilalis & 25 & 0.066 & 2.58 & 1.65 & 0.93 & 0.63 & 22 & 0.086 & 2.49 & 1.89 & 0.60 & 0.37 \\
\hline \multicolumn{13}{|c|}{$\begin{array}{l}\text { EXP }(\text { Expected yield })=\text { No. of plants }(\mathrm{N}) \times \text { Intact plant yield }\left(\mathrm{Y}^{*}\right) \\
\text { ACT }(\text { Actual plant yield })=\text { No. of plants }(\mathrm{N}) \text { xabsent or infested plant yield }(\mathrm{Y}) \\
\text { LOSS }=\text { EXP }- \text { ACT } \quad \% \text { LOSS }=\text { LOSS } / \text { EXP x } 100\end{array}$} \\
\hline \multicolumn{13}{|c|}{$\begin{array}{l}\text { Table 7: The percentages of reduction in yield losses of yellow corn due to infestation by stem } \\
\text { borers under treatment of insecticide. }\end{array}$} \\
\hline \multirow{2}{*}{ stem borers } & \multicolumn{4}{|c|}{$\%$ Yield losses } & \multirow{2}{*}{\multicolumn{3}{|c|}{ Decline in yield losse }} & \multirow{2}{*}{\multicolumn{5}{|c|}{$\%$ Reduction in yield losses }} \\
\hline & untrea & ated & treate & & & & & & & & & \\
\hline S. cretica & 0.75 & & 0.69 & & & 0.0 & & & & $8 \%$ & & \\
\hline O. nubilalis & 0.63 & & 0.37 & & & 0.2 & & & & $11.27 \%$ & & \\
\hline
\end{tabular}

Table 8: Estimation of grain yield losses due to three pests in untreated and treated sugary corn.

\begin{tabular}{|c|c|c|c|c|c|c|c|c|c|c|c|c|}
\hline \multirow[b]{3}{*}{ Plant status } & \multicolumn{6}{|c|}{ untreated } & \multicolumn{6}{|c|}{ treated } \\
\hline & \multirow{2}{*}{$\begin{array}{c}\text { No. of } \\
\text { plants } \\
(\mathrm{N}) \\
\end{array}$} & \multirow{2}{*}{$\begin{array}{c}\text { Plant } \\
\text { yield } \\
(\mathbf{k g})(\mathbf{Y})\end{array}$} & \multicolumn{4}{|c|}{ Grain yield (kg/plot) } & \multirow{2}{*}{$\begin{array}{c}\text { No. of } \\
\text { plants } \\
(\mathrm{N})\end{array}$} & \multirow{2}{*}{$\begin{array}{c}\text { Plant } \\
\text { yield } \\
(\mathrm{kg})(\mathrm{Y})\end{array}$} & \multicolumn{4}{|c|}{ Grain yield (kg/plot) } \\
\hline & & & EXP & ACT & Loss & $\begin{array}{c}\% \\
\text { Loss } \\
\end{array}$ & & & EXP & ACT & Loss & $\begin{array}{c}\% \\
\text { Loss } \\
\end{array}$ \\
\hline Intact & 1246 & $\begin{array}{c}0.036 \\
\left(\mathrm{Y}^{*}\right)\end{array}$ & 44.86 & 44.86 & 0 & 0 & 1277 & $\begin{array}{c}0.038 \\
\left(\mathrm{Y}^{*}\right)\end{array}$ & 48.53 & 48.53 & 0 & 0 \\
\hline Absent & 154 & 0 & 5.54 & 0 & 5.54 & 10.53 & 123 & 0 & 4.67 & 0 & 4.67 & 8.58 \\
\hline Infested with $S$. cretica & 24 & 0.034 & 0.864 & 0.816 & 0.048 & 0.09 & 12 & 0.02 & 0.46 & 0.24 & 0.22 & 0.40 \\
\hline Infested with O.nubilalis & 26 & 0.035 & 0.936 & 0.91 & 0.02 & 0.04 & 10 & 0.036 & 0.38 & 0.36 & 0.02 & 0.04 \\
\hline
\end{tabular}

EXP $($ Expected yield $)=$ No. of plants $(\mathrm{N}) \times$ Intact plant yield $\left(\mathrm{Y}^{*}\right)$

ACT $($ Actual plant yield $)=$ No. of plants $(\mathrm{N})$ xabsent or infested plant yield $(\mathrm{Y})$

LOSS $=$ EXP - ACT $\quad \%$ LOSS $=$ LOSS $/$ EXP $\times 100$ 
Table 9: The percentages of reduction in yield losses of sugary corn due to infestation by stem borers under treatment of insecticide.

\begin{tabular}{lccccc}
\hline stem borers & \multicolumn{2}{c}{$\%$ Yield losses } & & $\begin{array}{c}\text { Decline in yield } \\
\text { losses }\end{array}$ & $\begin{array}{c}\text { \% Reduction in yield } \\
\text { losses }\end{array}$ \\
\cline { 2 - 4 } Untreated & treated & & -0.31 & 0 \\
\hline Oretica & 0.09 & 0.4 & 0.04 & 0 & 0 \\
\hline Theilalis & 0.04 & 0.04 direct & feeding & on the corn leads to & yellow and sugary corn, respectively. That the
\end{tabular}
quantitative and qualitative yield losses varying between 20 and 80\%. In Kynia, Odendo et al.(2001) reported that yield loss was estimated to be $12.9 \%$, amounting to 0.39 million tonnes of maize, with an estimated value of 76 million US \$. High potential areas have relatively low crop loss levels (10-12\%). the dry mid-altitude zones, where losses total approximately175 kg/ha. The value of these losses is estimated at 61-75 US \$ / ha and 34 US \$/ha, respectively.

These results also previously confirmed by many authors such as Rao and Panwar (2002) who reported that stem borers cause 25-40 percent of yield loss based on pest population density and phonological stage of crop. In India, the actual loss in maize crop due to pests is about $40 \%$ (Oerka, 2006). (Getu et al., 2008), Estimated yield losses due to stem borer pests ranged between $20 \%$ and $50 \%$.

The percentage of yield losses that illustrated in Tables (4,6and 8) indicate the susceptibility of different untreated corn varieties to pest infestations, where the yield losses due to $S$. cretica infestation were $1.83,0.75$ and $0.09 \%$ for white, yellow and sugary corn, respectively. In case of O.nubilalis infestation, the yield losses were $1.38,0.63$ and $0.04 \%$ for white, yellow and sugary corn, respectively. These mean that the white corn was the most susceptible variety for $S$. cretica, and O.nubilalis infestations. On the contrary, the sugary corn was the most tolerable variety for the infestation with the investigated pests.

As the yield losses (infestation level) related with the corn variety, it was reported by many authors that oviposition of Sesamia, level of infestation and subsequently the yield losses affected by host plant, (Konstantopoulou et al., 2002;Sekharet al., 2009; Dimotsiou et al., 2013 and Salman et al.,2018). Also, the influence of transgenic and commercial corn hybrids on the behavior and feeding activity of the pink corn borer (S. cretica Led.) was investigated by Ismail et al. (2012), and they found that feeding ratio and food consumption of $S$. cretica on maize hybrids was significantly different according to corn hybrids. Metwally (2015) classified the tested maize cultivars into 5 significantly different susceptibility groups to infestation with $S$. cretica in Egypt.

On the other hand the yield losses due to plant absence were, $3.75,4.8$ and $10.53 \%$ for white, sugary corn has the highest percent of yield losses due to absent plants, this may be related with the weakness of sugary corn yield when compare with the white and yellow corn.

Generally, data in such Tables explain that insecticide treatments decrease the percent of yield losses. This result agree for a great extent with the findings of Mesbah et al. (2002b) who found that spraying the biofertilized corn plants in different sowing dates with the tested insecticides, significantly decreased the rate of the stem borers infestation than the untreated plants of control.

Under stressed conditions of increasing pollution problems and insecticidal hazard consequences, it is necessary to look for safer facilities for insect pest suppression. The use of tolerant varieties for pest infestation is a new trend which may prove efficient for pest control.

The level of yield losses under pest infestations is very important as mentioned by Al-Naggar et al. (2000) who reported that the yield under infestation conditions appears to be an important way to select the crosses with high yield when the insect attack is important.

2: Estimation of grain yield losses (kg/plot) of three corn varieties due to stem borers by conventional and analytical methods:

Estimation of grain yield losses (kg/plot) of three corn varieties due to stem borers by using conventional(insecticide treatment) and analytical method (Judenko, 1973)was illustrated in Table (10). Estimation by conventional method showed that percentages of yield losses were 8.59, 10.65 and $11.48 \%$ for yellow, white and sugary corn, respectively. While, estimation by analytical method showed that percentages of yield losses were 8.4, 6.81 and $10.74 \%$ for the three investigated varieties, respectively. Present results indicate that the analytical method was more accurate than the conventional method, whereas, analytical method put in consideration yield loss from absent plants during assessment of yield losses but conventional method estimate yield losses of only plant stands after sowing. However, Yield losses estimated by analytical method were lower than conventional method (Table 10). This may due to beneficial or converse effect of insecticide on the plant yield and arising compensatory yield in the stand plants neighboring to absent plants (Judenko, 1973). 
Table10: Estimation of grain yield losses (kg/plot) of three corn varieties due to stem borers, $S$. cretica and $\boldsymbol{O}$. nubilalis by using conventional and analytical methods.

\begin{tabular}{|c|c|c|c|c|c|c|c|c|}
\hline \multirow[b]{3}{*}{ Corn varieties } & \multicolumn{4}{|c|}{ Conventional method } & \multicolumn{4}{|c|}{ analytical method } \\
\hline & \multicolumn{2}{|c|}{ Actual yield/Plot } & \multirow[b]{2}{*}{ Loss } & \multirow[b]{2}{*}{$\%$ loss } & \multicolumn{2}{|c|}{ Yield on untreated plots } & \multirow[b]{2}{*}{ Loss } & \multirow[b]{2}{*}{ \%Loss } \\
\hline & Treated & Untreated & & & $\begin{array}{c}\text { Expected in } \\
\text { absence } \\
\text { infestation } \\
\end{array}$ & Actual & & \\
\hline Yellow corn & 154.2 & 140.96 & 13.24 & 8.59 & 153.88 & 140.96 & 12.92 & 8.4 \\
\hline White corn & 209.45 & 189.35 & 22.3 & 10.65 & 203.19 & 189.35 & 13.84 & 6.81 \\
\hline Sugary corn & 52.60 & 46.56 & 6.04 & 11.48 & 52.60 & 46.95 & 5.65 & 10.74 \\
\hline
\end{tabular}

\section{CONCLUSION}

The percentage of yield losses indicates the susceptibility of different untreated corn varieties to pest infestations, where the yield losses due to $S$. cretica infestation were $1.83,0.75$ and $0.09 \%$ for white, yellow and sugary corn, respectively. In case of $O$. nubilalis infestation, the yield losses were $1.38,0.63$ and $0.04 \%$ for white, yellow and sugary corn, respectively. These mean that the white corn was the most susceptible variety for $S$. cretica, and O. nubilalis infestations. On the contrary, the sugary corn was the most tolerable variety for the infestation with the investigated pests.

\section{REFERENCES}

Abd El- Gawad, H. A. S., El- Khawas, M. A. M., \& El-Bishry, M. H. (2002). Combined effects of entomopathogenic nematodes and biofungicide on two corn borers, Sesamiacretgica Led. (Lepidoptera: Noctuidae) and Ostrinianubilalis (Hubn.) (Lepidoptera: Pyralidae). $2^{\text {nd }}$ International Conf., Plant Protection Research Institute, Cairo, Egypt, 21-24 December 2002.

Abd El-Mageed, A. E. M., \& El-Gohary, L. R. A. (2007). Possibility of replacing the conventional insecticides with safety environmental compounds in controlling the two corn borers Sesamiacretica Led. andOstrinianubilalis Hun. Journal ofEntomology, 4(6), 451-456.

Abdel Rahim, M. M., Abdel Fattah, M. I., Farag, A. I., \& El-Naggar, M. A. Z. (1992). Contribution to the study of the corn leaf aphids Rhopalosiphummaidis Fitch, on maize plants. Bull. Entomol. Soc. Egypt, 70, 91-98.

Al-Eryan, M. A. S., \& El-Tabbakh, S. Sh. (2004). Forecasting yield of corn, Zea mays infested with corn leaf aphid, Rhopalosiphummaidis. Blackwell Verlag, Berlin, JEN 128(4) doi: 10.1111/j.1439-0418.2004.00852, 312-315.
Al-Naggar, A. M., El-Ganayni, A. A., El-Lakany, M. A., El-Sherbeiny, H. Y., \&Soliman, M. S. M. (2000). Mode of inheritance of maize resistance to the pink stem borer Sesamiacretica Led. under artificial infestation. Egbt Journal of Plant breed, 4, 13-35.

Ande, O. T., Adediran, J. N., Ayola, O. T., \&Akinlosotu, T. A. (2008). Effects of land quality management and cropping on cassava production in South Western Nigeria. African Journal of Biotechnology, 7(14), 2368-2374.

Bergstrom, G. C., \& Nicholson, R. L. (1999). The biology of corn anthracnose; knowledge to exploit for improved management. Plant disease, 83, 596-607.

Chiarappa, L., Moor, F. J., \& Strickland, A. H. (1970). Introduction. In crop loss assessment methods. FAO manual on the evaluation and prevention of losses by pests, diseases and weeds. Rome, FAO, pp. 1/1-1/4.

Dimotsiou, O. C., Andreadis, S. S., \&SavopoulouSoultani, M. (2013). Egg laying preference of Sesamianonagrioides (Lepidoptera: Noctuidae) among primary and secondary hosts. Appl. Entomol. Zool. 49, 27-33.

FAO (Food and Agricultural Organization) (1998). FAO Production Bulletin FAO, Rome pp. 3440.

Gage, S. H., \&Mukerji, M. K. (1978). Crop Losses Associated with Grasshoppers in Relation to Economics of Crop Production. Journal of Economic Entomology, 71(3), 487-498.

Getu, E., Tadesse, A., Negeri, M., Tefera, T., Tsaheye, H., \&Dejene, A. (2008). Review of entomological research on maize, sorghum and millet. In A. Tadesse (Ed.), increasing crop production through improved plant protection (pp. 167-244). Addis Ababa, Ethiopia: Plant Protection Society of Ethiopia. 
Golebiowska, Z., \&Romankov, W. (1968). Trials to assess losses caused by cecidomyid larvae to foxtail-grass (Alopecuruspratensis L.). (In polish with English and Russian summaries.) Roczn, Naukroln. (A), 93, 685-699.

Idraw, M. W., \& Al-Jouri, E. (2007). Monitoring the effect of some insecticides for corn stem borer control at DeirEzzor region, Syria. Arab Univ. Journal of Agriculture Science, 15(2), 301- 312.

Ismail, I. I., Semeada, A. M., \& El-Salam, A. (1993). Seasonal occurrence and host rang of the corn leaf aphid Rhopalosiphummaidis Fitch at Giza and Qualubia Governorates. Bull. Entomol. Soc. Egypt, 71, 33-40.

Ismail, I. A.; Abdel-Moniem, A. S. H.; El-Shazly, E. A.; H El-Shabrawy. A. and Abdel-Rahman, R. S. (2012): Biodetrimental effects of the corn hybrids, Neemazal-T/S and Chlorphan $48 \%$ on the pink corn borer Sesamiacretica Led. Archives of Phytopathology and Plant Protection; 45(17):2014-2025. 25 ref.

Judenko, E. (1973). Analytical Methods for Assessing Yield Losses Caused by Pests on Cereal Crops with and without Pesticide. Tropical Bulletin No. 2. Center for Overseas Pest Research, UK, pp.31.

Konstantopoulou, M. A., Krokos, F. D., \&Mazomenos, B. E. (2002). Chemical stimuli from corn plants affect host selection and oviposition behavior of Sesamianonagrioides(Lepidoptera:

Noctuidae). Journal of Economic Entomology, 95(6), 1289-1293.

Kumar, R. (1984). Insect Pest Control, with special reference to African agriculture. Edward Arnold (Publishers) Ltd, 298 pp.

Lubischev, A. A. (1932). On the problem of calculation of the amount of damage caused by injurious insects. (In Russian.) Zashch. Rast. Vredit., 8, 472-488.

Mansour, M. H., Salem, N. Y., Amr, E. M., \& Salem, H. A. (1994). Injury levels and yield loss model for the corn aphid, Rhopalosiphummaidis (Fitch) on corn, Zea mays (L.). Bull. Entomol. Soc. Egypt, 72, 217-227.

Massoud, M. A., Zaghloul, O. A., Barakat, A. S. Ebieda, A. M., \&Amr, A. A. (2016). Assessment of Maize Yield Loss to Determine Economic Injury Levels (Eils) Due To the Infestation by Stem Borers with Insecticidal Control under the Egyptian Conditions. Alexandria Science Exchange Journal, 37(4), 729-737.
Mbah, C. N., Nwite, J. N., \&Nweke, I. A. (2009). Amelioration of spent Oil Contaminated Ultisol with Organic Wastes and its effects on soil properties and maize (Zea mays L.) yield. World Journal of Agriculture Sciencs, 5(2), 163-168.

Mesbah, H. A., Mourad, A. K., El-Nimr, H. M., Massoud, M. A., \&Abd El-Aziz, A. A. (2002a). The role of some agricultural practices and fertilizer type on both the incidence of stem borers infestation and corn yield in Egypt. Mededelingen (Rijksuniversiteitte Gent. Fakulteit van de Landbouwkundige

ToegepasteBiologischeWetenschappen) 67(3), 575-589.

Mesbah, H. A., Mourad, A. K., El-Nimr, Hanyiat, M., El-Kady, Magda, B. \&Haroun, Nagah, S. (2002b). Effect of sequential applications of foliar nutrients, biofertilizers and sowing dates on the incidence of corn stem borers in Egypt. Mededelingen (Rijksuniversiteitte Gent. Fakulteit van de Landbouwkundige en ToegepasteBiologischeWetenschappen) 67(3):487-97 .

Metwally, Sameha A. (2015). The Relative Susceptibility of Certain Maize (Zea mays L.) Cultivars To Infestation With The Pink Stem Borer SesamiaCretica Led. (Lepidoptera: Noctuidae). M.Sc. Thesis, Faculty of Agriculture, Cairo University, 132.pp.

Odendo, M., De Groote, H. \&Odongo, O. M. (2001). Assessment of Farmers' Preferences and Constraints to Maize Production in the Moist MidaHitude Zone of Western Kenya. African Crop Science Conference Proceedings. Vol 5, pp. 769-775.

Oerka, E. C. (2006). Crop losses to pest. Journal of Agricultural Science. 144, 31-43.

Paulian, F., Mustea, D., Brudea, V., Banita, E., Enica, D., Peteanu, S., Petcu, L., Sapunaru, T., \&Sandru, I. (1976). The evolution of the European corn borer, Ostrinianubilalis Hbn. and the damaging potential recorded between 1971-1975 in R.S. Romania. Problems of Plant Protection, 4(1), 23- 51.

Pickett, A. D. (1954). Rep. $6^{\text {th }}$ Commonw. ent. conf. pp.87.

Rao, C.N., \&Panwar, V. P. S. (2002). Biochemical plant factors affecting resistance to Chilopartellus(Swinhoe) in maize. Annual of Plant Protection Science, 10, 115-119.

Sabbour, M. M. (2002). Evaluation studies of some bio-control agents against corn borers in Egypt. Annals of Agricultural Science (Cairo), 47(3), 1033-1043. 
Salman, Ahmed M. A., Abd El-AleemDesoky, S. S., SaadiaAbd-El-Samea, A., \& Mohamed Youssef, A. M. (2018). Larval Feeding and Ovipositional Preference of Sesamia Cretica Led. on Certain Corn Hybrids. International Journal of Research Studies in Agricultural Sciences (IJRSAS), Vol. 4, Issue 1, PP. 25-28.

Sekhar, J. C., Kumar, P., Rakshit, S., Singh, K. P., and Dass, S. (2009). Differential Preference for Oviposition by Sesamiainferens Walker on Maize Genotypes. Ann. Pl. Protec. Sci., 17 (1), 46-49.

Walker, P. T. (1967). A survey of losses of cereals to pests in Kenya and Tanzania. In Background Papers prepared for the FAO Symp. On crop losses, Rome, 2-6 October 1967. Rome, FAO. pp. 79-84.
White, D. G. (1999). Fungal stalk rots. Pages 33844 in: Compendium of corn diseases. $3^{\text {rd }}$ ed. American Phytopathological Society Press, St. Paul, MN.Wiatrak, P. J. D., L Wright, J. J. Marios, and D. Wilson. 2005. Influence of planting date on aflatoxin accumulation in $\mathrm{Bt}$, non Bt and Tropical non Bt hybrids. Agronomy Journal. 97, 440-445.

Zeren, O., Güllü, M., \&Şimşek, N. (1988). Some biological investigations relating to the control of stalk borer (Sesamiaspp.) and European corn borer (Ostrinianubilalis Hbn.) on corn in Mediterranean Region. Proceedings of a Symposium on Corn Borers And Control Measures, 1-3 November Adana, 1-19.

\section{الماخص العربى}

\section{تقدير الفاقد فى محصول ثلاثة أصناف من الأرة الشامية المتسبب عن حفارات الساق

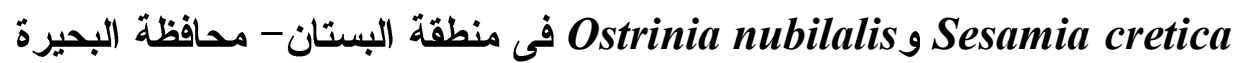

$$
\text { قسم علم الحثر ات و الحيوان التطبيقي - كلية الزبان شال، هناء حسين، هادي إبراهيم - جامعة الإسكندرية }
$$

تهدف الدراسة الحالية لتقدير الفاقد فى محصول ثلاثة أصناف من الذرة الثامية (البيضاء و الصفر اء و السكرية) و المتسبب عن حفار ات الساق Ostrinianubilalis Sesamiacretica تحت الظروف الحقلية و المعاملة بالمبيدات. وقد تم تقدير الفاقد بالطريقتين التقليدية و التحليلية لمقارنة أيهما أكثر دقة فى التقدير . أوضحت نتائج الدراسة أن وزن الحبوب فى الكوز للنباتات السليمة يتأثز معنوياً بإختاف صنف الذرة، فى حين أنه لا يتأثر بالمعاملة بالمبيدات. وقد سجل صنف الذرة البيضاء أعلى وزن للحبوب على الكوز (سب,؛ (جم)، وفى المقابل تم تسجيل أقل وزن فى صنف الذرة السكرية (بسجم). لوحظ إنخفاض وزن الحبوب على الكوز بوضوح نتيجة الإصابة بحفارات الساق Ostrinia nubilalis و Sesamia cretica، وكان صنف الذرة البيضاء هو الأكثر حساسية للإصابة. أدت المعاملة بالمبيدات إلى خفض معدلات الفقد فى المحصول الناتج عن الإصابة بكل من \% Ostrinia nubilalis Sesamia cretica

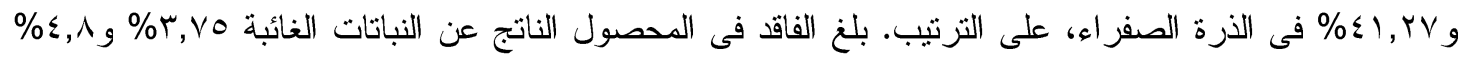
و سه, • (1\% لأصناف الذرة البيضاء و الصفر اء و السكرية، على الترتيب. تشير النتائج أيضاً إلى أن الطريقة التحليلية كانت أكثر دقة فى تقدير الفاقد فى المحصول مقارنة بالطريقة التقليدية، حيث أنه فى الطريقة التحليلية يوضع فى الإعتبار الفاقد فى المحصول الناجم عن النباتات الغائبة أثثاء ثقدير الفقد فى المحصول. 